DOI: $10.35757 /$ CIV.2011.13.12

\title{
Tradycja klasyczna i jej krytycy
}

W. Julian Korab-Karpowicz, Historia filozofii politycznej. Od Tukidydesa do Locke'a. Tradycja klasyczna i jej krytycy, seria „Daimonion. Fundamenta", t. 64, Wydawnictwo Marek Derewiecki, Kęty 2010, ss. 385.

Pod koniec roku 2010 do księgarń trafiła nowa książka stanowiąca przekrojowe opracowanie $z$ zakresu dziejów myśli filozoficznopolitycznej oraz filozoficznoprawnej. Nosi ona tytuł Historia filozofii politycznej. Od Tukidydesa do Locke'a, opatrzony zreszta na karcie tytułowej wymownym podtytułem Tradycja klasyczna $i$ jej krytycy. Jej autorem jest doktor Uniwersytetu Oksfordzkiego i profesor Anglo-Amerykańskiego Uniwersytetu w Pradze oraz profesor wizytujący na kilku innych uczeniach zagranicznych - Włodzimierz Julian Korab-Karpowicz ${ }^{1}$. Jest to pierwsza polskojęzyczna pozycja ksiażkowa tego polskiego naukowca, który swoje prace publikował dotąd głównie w języku angielskim. Ze względu zatem zarówno na charakter dzieła, jak i jego tematykę wypada przedstawić je tutaj bardziej szczegółowo.

$\mathrm{Na}$ początku należy zaznaczyć, że recenzowana książka różni się pod względem sposobu ujęcia zagadnienia od dotychczasowych opracowań, które w tytule zawierały określenia: „historia doktryn politycznych” czy też „historia myśli politycznej”. Przede wszystkim nie urasta do rangi kompendium wiedzy na temat wszystkich doktryn politycznych, które od starożytności aż po początek wieku XVIII odegrały jakąś rolę $\mathrm{w}$ historii ludzkiej kultury i cywiliza-

1 Włodzimierz Julian Korab-Karpowicz jest autorem kilku książek i wielu artykułów z dziedziny filozofii polityki, w tym tekstów opublikowanych w encyklopediach: Internet Encyclopedia of Philosophy i Stanford Encyclopedia of Philosophy. Ukazanie sie nowej angielskiej wersji jego Historii filozofii politycznej, zatytułowanej On the History of the Political Philosophy. From Thucydides to Locke, zapowiadane jest przez wydawnictwo Pearson Education na rok 2012. 
$\mathrm{cji}^{2}$ ani nie ma charakteru podręcznika. Autor dokonuje świadomego wyboru i skupia uwage na postaciach dziesięciu myślicieli, których uznaje za najważniejszych, w celu uchwycenia oraz zrozumienia rozwoju poglądów na temat polityki, państwa, prawa i stosunków międzynarodowych w europejskim kręgu kulturowym we skazanym w tytule okresie. Sa to: Tukidydes, Platon, Arystoteles, Cyceron, św. Augustyn, św. Tomasz z Akwinu, Niccolò Machiavelli, Hugo Grocjusz, Thomas Hobbes oraz John Locke. Oprócz tego $\mathrm{w}$ zakończeniu - w charakterze swoistego epilogu - znalazło się krótkie omówienie poglądów „ojców założycieli” Stanów Zjednoczonych Ameryki. Takie zreszta podejście uzasadnione jest zamiarem autora, który chciał stworzyć historię „filozofii politycznej”, a nie omówienie historyczne najważniejszych twórców doktryn politycznych ${ }^{3}$. Książka zatem $z$ założenia ma nie tylko charakter historyczny, lecz również filozoficzny.

Każdy $z$ obszernych, niekiedy ponadtrzydziestostronicowych ${ }^{4}$, esejów poświęconych określonemu myślicielowi zawiera, oprócz prezentacji jego życiorysu, wprowadzenie o charakterze historycznym, omawiające ważne wydarzenia epoki, które miały wpływ na ukształtowanie jego poglądów. Można się zastanawiać, czy rozbudowane wyjaśnienia historyczne są zawsze potrzebne, zwłaszcza że w większości przypadków przedstawione w nich treści łatwo znaleźć w innych pracach, choć $z$ pewnościa przybliżają one - zwłaszcza czytelnikowi niebędącemu historykiem lub specjalistą w zakresie myśli

\footnotetext{
2 Charakter kompendiów maja opracowania leksykonowe: M. Maciejewski, E. Kundera (red.): Leksykon myślicieli prawnych i politycznych, C.H. Beck, Warszawa 2009, ss. 639; H. Olszewski: Słownik twórców idei, Wydawnictwo Poznańskie, Poznań 2001, ss. 474. Nie można też zapomnieć o obszernym encyklopedycznym wydawnictwie przygotowywanym przez krakowskich badaczy pod redakcją Michała Jaskólskiego: Słownik historii doktryn politycznych, t. 1-4, Wydawnictwo Sejmowe, Warszawa 1997-2009.

3 Jest to zreszta pierwsza dokonana przez polskiego autora próba ujęcia dziejów „filozofii politycznej”. Warto wskazać, że niemal równolegle na półki księgarskie trafił przekład klasycznego, choć już nienowego, opracowania Josepha Cropseya i Leo Straussa. Zob. J. Cropsey, L. Strauss (red.): Historia filozofii politycznej, przekład P. Nowak, M. Wiśniewski i in., Fronda, Warszawa 2010, ss. 984. Publikacje te maja jednak różny charakter, co wynika choćby $z$ prostego faktu, że recenzowana praca jest dziełem jednego twórcy, a nie zbiorowym wysiłkiem zespołu naukowców, mających różne stanowiska i warsztat badawczy.

${ }_{4}$ Dotychczasowe kompendia $\mathrm{z}$ zakresu historii doktryn polityczno-prawnych lub myśli politycznej oferują najwyżej 4-5-stronicowe omówienia dorobku poszczególnych myślicieli.
} 
politycznej - problemy czasu, w którym powstała dana doktryna. $\mathrm{W}$ moim przekonaniu najciekawsze, a przy tym integralnie zwiazane $z$ treścia rozdziałów, sa dwa $z$ owych wstępów: Blaski $i$ cienie renesansu, poprzedzający rozważania o myśli Machiavellego, oraz Rewolucja naukowa, który zamieszczony jest przed omówieniem doktryny Hobbesa. Same analizy poglądów poszczególnych filozofów sa natomiast podzielone problemy i zagadnienia, co należy uznać za bardzo trafne rozwiąanie autora, gdyż ułatwia koncentrację na głównych składnikach poglądów danego myśliciela.

Gdyby chcieć jednym określeniem scharakteryzować treść recenzowanej ksiażzki, należałoby powiedzieć, że stanowi ona historię pojęcia cnoty w myśli politycznej. Autor bardzo trafnie wskazuje bowiem, że tradycję klasyczna - a więc antyczna i chrześcijańską, aż po czasy odrodzenia - wyznacza stosunek do moralności $\mathrm{w}$ sferze politycznej, tj. opieranie się na uniwersalistycznej teorii etycznej, której kluczowym elementem jest kategoria cnoty. Warto zacytować znamienny fragment: „[...] tradycja klasyczna to tradycja moralna, która wyłoniła się w myśli politycznej Zachodu. Obejmuje myślicieli, dla których polityka jest nieodłącznie związana $z$ etyka i którzy podkreślali wagę cnót w życiu publicznym" (s. 9).

Początki namysłu nad relacją między polityką a moralnościa sytuuje autor $\mathrm{w}$ refleksji Tukidydesa, którego interesujacco przedstawia jako prekursora realizmu $\mathrm{w}$ teorii stosunków międzynarodowych. Autor Wojny peloponeskiej jest $z$ reguły opisywany jako historyk, rzadko zaś uważa się go za ważnego myśliciela politycznego. Dlatego też rozdział poświęcony Tukidydesowi z poznawczego punku widzenia uznać trzeba za pewną wartość publikacji.

Interpretacje zaprezentowane $\mathrm{w}$ książce, jakkolwiek osadzone sa w literaturze przedmiotu, a także obficie okraszone cytatami $z$ dzieł omawianych filozofów, noszą znamię indywidualności autora. Warto więc w tym miejscu przyjrzeć się im bliżej, wskazując kilka przykładów. Analizując myśl Platona, Korab-Karpowicz podaje w wątpliwość jej utopijny charakter, stwierdzając, że grecki filozof nie miał na celu realizacji swojej wizji państwa zawartej w dialogu 
Państwo. Stanowi ona raczej ilustrację „głównej tezy dialogu, która głosi, że sprawiedliwość będąca uniwersalną wartością moralna jest podstawa doskonałego porządku moralnego" (s. 50). Niejako konsekwencja takiego pogladu jest polemika $z$ rozpowszechnionym w literaturze od czasów Karla R. Poppera ${ }^{5}$ przeświadczeniem, że utopia Platońska stanowiła prototyp państwa totalitarnego (s. 56). Arystoteles - mimo że dość powszechnie podkreśla się jego empiryzm, a tym samym zakorzenienie w greckim „tu i teraz” ${ }^{6}$ - został uznany za idealistę politycznego (s. 70). Na uwage zasługuje też przedstawiona $\mathrm{w}$ pracy interpretacja Arystotelesowskiego ustroju mieszanego (s. 88-91). Omawiając myśl Cycerona, autor wskazuje na związki między Cycerońską a Grocjańską koncepcja stosunków międzynarodowych (s. 116-121). Trafnie akcentuje również teorię cnoty i republikanizm rzymskiego oratora, przyznając jednak, że republikanizm ów oznaczał poparcie dla ustroju, który uważano za wariant ustroju mieszanego, w którym władzą dzieliły się różne klasy społeczne (s. 124-127) ${ }^{7}$. Dyskutujac na temat systemu republikańskiego, należy pamiętać o tym właśnie klasycznym rozumieniu owego pojęcia.

Wyróżnić wypada przedstawiona w pracy ciekawa interpretację koncepcji św. Augustyna, wedle której biskup Hippony nie był bynajmniej całkowitym i nieustępliwym wrogiem „państwa ziemskiego", a w jego myśli przewijają się wattki realistyczne (s. 147-150) ${ }^{8}$. Ponadto Korab-Karpowicz na pierwszy plan wysuwa antyimperializm Augustyna, uznając, iż jest to idea wciąż aktualna.

Sposób, w jaki została w pracy ujęta podstawowa różnica między myślą antyku i chrześcijaństwa należy uznać za przekonujący

\footnotetext{
${ }_{5}$ Zob. K.R. Popper: Społeczeństwo otwarte i jego wrogowie, t. 1: Urok Platona, przekład H. Krahelska, Wydawnictwo Naukowe PWN, Warszawa 1993, s. 108 i nast.

6 Zob. np.: K. Chojnicka, H. Olszewski: Historia doktryn politycznych i prawnych. Podręcznik akademicki, Przedsiębiorstwo Wydawnicze „Ars boni et aequi”, Poznań 2004, s. 26; J. Baszkiewicz, F. Ryszka: Historia doktryn politycznych i prawnych, Państwowe Wydawnictwo Naukowe, Warszawa 1984, s. 52.

7 Zob. też: L. Dubel: Historia doktryn politycznych i prawnych do schyłku XX wieku, Lexis-Nexis, Warszawa 2009, s. 79-82.

8 Dla zupełnie innej interpretacji zob. m.in.: J. Baszkiewicz, F. Ryszka: Historia doktryn..., s. $101-102$.
} 
i uzasadniony: o ile dla starożytnych dobrem najwyższym było szczęście, tj. życie dobre we wspólnocie politycznej, polegające na uprawianiu cnoty i moralnym oraz intelektualnym doskonaleniu się, o tyle dla myślicieli chrześcijańskich takie dobro stanowiła łaska Boża, dzięki której można uniknąć grzechu, a więc kategorii obcej starożytności niechrześcijańskiej (s. 142-143). Jednocześnie autor $z$ cała stanowczością podkreśla, że chrześcijaństwo nie dokonało prostej negacji myśli grecko-rzymskiej, lecz w wielu aspektach stanowiło jej kontynuację, co pozwala mówić o jednej tradycji klasycznej. Na dowód tego akcentuje w swoich analizach dzieł Augustyna i św. Tomasza $z$ Akwinu kwestię cnót obywatelskich, ukazując, że w tej materii nie ma radykalnego zerwania ciagłości między refleksja antyczna a średniowieczną. Rzecz jasna - co zostaje w książce uwypuklone - oba sposoby myślenia o polityce spotykaja się najbardziej w filozofii Akwinaty, który, jak starożytni, odwoływał się do społecznej natury człowieka, wskazując, że instytucja rządu jest konieczna nie ze względu na grzeszność ludzi, ale $z$ racji takiej, a nie innej, konstrukcji ich natury, która pochodzi od Boga, wobec czego również władza ma Boskie umocowanie (zob. s. 177-178). W ten sposób Tomasz polemizował z poglądami Ojców Kościoła, a zwłaszcza Augustyna, i zredefiniował - w duchu antycznym - tezę o boskim pochodzeniu władzy.

Odrodzeniowy humanizm to, według Korab-Karpowicza, ostatni prąd, który w pełni należał do formacji klasycznej (s. 201-204). Wyraża on zarazem kontrowersyjny i sprzeczny z czołowym w literaturze stanowiskiem ${ }^{9}$ pogląd, według którego myśl Machiavellego nie tylko nie zalicza się do tegoż prądu intelektualnego, ale stanowi pierwsza krytykę klasycznego nurtu refleksji politycznej (s. 9, $208)^{10}$. Ponadto wysuwa przeciw Machiavellemu ciężkie oskarżenia o militaryzm i usprawiedliwianie dążeń ekspansjonistycznych (s. 224-229). Nie neguje jednak wpływów antycznych w jego doktrynie, która prezentując swoisty manicheizm i odcinając się

9 Zob. S. Filipowicz: Historia myśli polityczno-prawnej, Arche, Gdańsk 2002, s. 148-149.

${ }^{10}$ Nieco podobnie: L. Dubel: Historia doktryn..., s. 120. 
od klasycznej filozofii moralnej, jest wszak w pewien sposób w niej zakorzeniona (s. 211-216, 230-232). Za nawiazanie do owej „klasyczności" można przecież uznać obecne u Machiavellego podkreślanie kategorii dobra ogólnego.

Z kolei Grocjusz został ukazany przez Korab-Karpowicza jako myśliciel twórczo nawiązujący do tradycji klasycznej i usiłujący ją odnowić, a także krytyk stanowiska Machiavellego (s. 248-252). $\mathrm{Za}$ interesujacy - jakkolwiek spotykany już $\mathrm{w}$ literaturze ${ }^{11}$ - należy uznać wyrażony w rozdziale poświęconym Grocjuszowi pogląd, że holenderski prawnik jest prekursorem koncepcji interwencji humanitarnej (s. 262-266). Thomasa Hobbesa natomiast uważa autor za ojca nowoczesności lub, jak to określa, „moderności”. W jego opinii był to nie tylko filozof, który przedstawił model człowieka, zajmującego się pomnażaniem dóbr oraz potęgi - prawzór homo oeconomicus ${ }^{12}$, ale także który radykalnie zerwał $z$ myślą antyczną i chrześcijańska, kładąc tym samym podwaliny pod nowoczesny pozytywizm - zarówno filozoficzny, jak i prawniczy (s. 302-304). Autor kwestionuje również - akceptowana niekiedy w literaturze ${ }^{13}$ - przynależność Hobbesa do szkoły prawa natury. W analizie poglądów Locke'a zwraca zaś uwagę omówienie pojęcia tolerancji religijnej (s. 319-322). Polski filozof stawia też tezę, że już w poglądach ideologa "chwalebnej rewolucji” można znaleźć - charakterystyczny dla liberalizmu - podział na sferę prywatna i publiczna. Wypada również zauważyć wskazanie, najczęściej znajdujących się

${ }^{11}$ Zob. J. Zajadło: Ius ad bellum, ius ad interventionem, czyli historia humanitarnej interwencji, w: idem: Studia Grotiana, Arche, Gdańsk 2004, s. 190-195.

${ }^{12}$ Nie jest pogląd nowy. Już u schyłku XIX wieku sugerował to Ferdinand Tönnies (zob. F. Tönnies: Tomasz Hobbes. Życie jego i nauka, przekład: L. Karpińska, Warszawa 1903, s. 272-273). Warto wspomnieć, że model takiego człowieka - wbrew rozpowszechnionej opinii - nie pochodzi od „ojca” nowoczesnej teorii ekonomii, Adama Smitha, lecz jest zwulgaryzowana wersją rozważań Johna Stuarta Milla. U Smitha bardzo mocno zauważalne są inspiracje klasyczna, stoicka teorią cnót, a człowiek gospodarujący - oszczędny czy też pożyteczny (a frugal man) - jaki pojawia się w Badaniach nad natura i przyczynami bogactwa narodów, jest prowadzacym działalność ekonomiczną cnotliwym „człowiekiem rozważnym” (a prudent man), o którym mowa w Teorii uczuć moralnych (zob. A. Smith: Badania nad natura i przyczynami bogactwa narodów, t. I, przekład S. Wolff, O. Einfeld, Z. Sadowski, Wydawnictwo Naukowe PWN, Warszawa 2007, s. 382 i nast.; D.D. Raphael, A.L. Macfie: Introduction, w: A. Smith: The Theory of Moral Sentiments, Liberty Fund, Indianapolis 1984, s. 9, 18).

${ }^{13}$ Zob. R. Tokarczyk: Klasycy prawa natury, Wydawnictwo Lubelskie, Lublin 1988, s. 189-203. 
poza zainteresowaniem badaczy, elementów merkantylistycznych w myśli Locke'a oraz uzasadnienie kolonializmu, jakie podał ten angielski myśliciel (s. 338-343).

Warto dodać, że Korab-Karpowicz poświęca w swojej pracy nieco miejsca refleksji prawnej. Na przykład omawiając spór między pozytywizmem prawniczym a koncepcja prawa natury, stawia interesująca tezę, że jego istota jest konflikt między woluntaryzmem a klasycznie pojętym racjonalizmem (s. 185-188).

W zakończeniu, poświęconym federalistom, autor ukazuje - bardzo trafnie - obecne w refleksji „ojców założycieli” nawiązania do antycznej myśli republikańskiej oraz do doktryny Locke'a, zaznaczając jednocześnie, że pragnęli oni wykreować taki ustrój republikański, który byłby zgodny $z$ duchem XVIII stulecia, tzn. gwarantujący równość wobec praw i dostosowanie do wymagań rodzącej się gospodarki kapitalistycznej (s. 349-351) ${ }^{14}$. Niemniej, wbrew własnym intencjom, doprowadzili do tego, że moment, w którym cnoty obywatelskie przestaną być uważane - by użyć cytowanego w pracy określenia Johna G.A. Pococka - za konieczna podstawę wolnego rządu, stał się tylko kwestia czasu. Wypada przychylić się do przekonująco uargumentowanego stanowiska autora, iż tym samym następowało przejście od tradycji klasycznej do wczesnej nowoczesności (zgodnie $z$ terminologia przyjętą w książce: „moderności"), łatwo rezygnującej z klasycznego pojęcia cnót.

Włodzimierz Julian Korab-Karpowicz nie kryje swoich przekonań i opinii. Pisze na przykład, iż „[...] jest w Tomaszu głębia myśli, do której daleko modnym dzisiaj autorom. Jego pisma moga być dla nas nadal źródłem idei i inspiracji” (s. 160). Trudno o wyrazistsze opowiedzenie się za takim sposobem refleksji teoretycznej, który twórczo nawiazywałby do tradycji klasycznej (por. też s. 356-357). Nie sposób jednak czynić autorowi $z$ tego zarzutu. $\mathrm{W}$ naukach humanistycznych i społecznych niełatwo bowiem cał-

\footnotetext{
${ }^{14} \mathrm{Na}$ marginesie warto dodać, że podobna tendencję - polegającą na dostosowaniu republikanizmu i cnót obywatelskich do współczesnych warunków społeczno-ekonomicznych - można dostrzec w myśli politycznej szkockiego oświecenia, a zwłaszcza w rozważaniach Adama Fergusona (1723-1816).
} 
kowicie uciec od własnych zapatrywań i światopoglądu. Można jedynie próbować je mniej lub bardziej udatnie ukryć. A tym, do czego należy dążyć, jest należyte pod względem metodologicznym i logicznym uzasadnienie przyjętego stanowiska. Pozór całkowitej obiektywności jest zaś najczęściej maską, pod która kryje się albo obłuda, albo brak refleksji.

Nie rezygnujac $z$ warsztatu naukowego, Korab-Karpowicz stara się uczynić swoją książke przystępna i ciekawą również dla osób niezajmujących się na co dzień myśla polityczną. Sądzę, że zaproponowany przez niego sposób narracji znakomicie przemówi do takich właśnie czytelników. Język pracy jest niezwykle przejrzysty, a styl - potoczysty, co sprawia, że w żadnym momencie lektura nie nuży i nie męczy. W tym sensie - nie zaś pod względem zawartości intelektualnej - książkę można określić mianem popularnonaukowej.

Podsumowując, trzeba stwierdzić, że na polskim rynku księgarskim znalazła się jeszcze jedna bardzo interesująca pozycja, do której $z$ pożytkiem może sięgnać zarówno obeznany $z$ tematyka historyk, prawnik lub politolog, jak i czytelnik poszukujacy przystępnie podanej wiedzy z zakresu myśli politycznej. Niewątpliwa wartością ksiażki jest znaczna doza oryginalności przedstawionych w niej interpretacji, a dodatkowa zaleta - próba ukazania nie tylko historycznej zmienności poglądów na temat państwa, polityki, sprawiedliwości czy też teorii stosunków międzynarodowych, ale także ujęcia ewolucji tych poglądów. Książka, która napisał Korab-Karpowicz, w żaden sposób nie zastępuje dotychczasowych kompendiów wiedzy $z$ zakresu historii doktryn politycznych czy myśli politycznej, ma bowiem od nich odmienny charakter, choć stanowi doskonałe ich uzupełnienie i wzbogacenie o nowe spojrzenie.

Piotr Szymaniec

Piotr Szymaniec - doktor nauk prawnych, Wrocław. 